IFN Working Paper No. 824, 2010

\title{
Housing Policies in China: Issues and Options
}

\section{Yves Zenou}




\title{
Housing Policies in China: Issues and Options ${ }^{1}$
}

\author{
by \\ Yves Zenou $^{*}$ \\ February 17, 2010
}

\begin{abstract}
This article consists in three parts. The first part deals with theory. We evaluate the pros and cons of government involvement in urban housing and of renting versus ownership. In the second part, we summarize the different housing policies that have been implemented in the United States, Europe, and Asia. We draw some conclusions. In particular, we show that there is a tradeoff between encouraging home ownership and social housing since countries that have favor the former have neglected the latter (like Japan, Spain, etc.). In the third part, we use the theory and the international policy parts to address housing policy issues in China. One of the main concerns in Chinese cities is the raise of poverty mainly by "illegal" migrants (who are Chinese rural residents) living in "urban villages". We propose two steps to fight against poverty in Chinese cities. The first one is to require that the Chinese government recognizes these "illegal" migrants by helping them becoming "legal". The second step is to encourage social housing that directly or indirectly subsidizes housing for the poor. In that case, to fight against poverty, one can either implement place-targeted policies (like the enterprise zone programs in the US and Europe and/or housing projects in the US, UK, or France) or people-targeted policies (like the MTO programs in the US). We also discuss other issues related to poverty. In particular, we suggest that the government could also try to keep migrants in rural areas by attracting firms there and/or introduce a microfinance system that helps them become entrepreneur.
\end{abstract}

JEL Classification: H5, O53.

Keywords: urban villages, social housing, poverty, place-targeted policies, people-targeted policies, China.

\footnotetext{
${ }^{1}$ I would like to thank Vernon Henderson, John Quigley and Ian Porter for very helpful comments. This paper was written while I was visiting the department of economics at the University of California, Berkeley. Their hospitality is gratefully acknowledged. I'm also grateful to Almega for financial support.

* Stockholm University and the Research Institute of Industrial Economics (IFN), Stockholm, Sweden. E-mail: yves.zenou@ne.su.se.
} 


\section{Introduction}

China is an amazing and unusual country. At the end of 2008, China's total population was 1.33 billion, with 723 million (54\%) and 607 million (46\%) residing in the rural and urban areas, respectively. The rural population fraction was 64\% in 2001 and $74 \%$ in 1990 . About $94 \%$ of population lives on approximately $46 \%$ of land. Despite these amazing figures, inequalities, slums and poverty have started to rise in Chinese cities partly because of the very-market oriented housing policies implemented in the last decades and partly because of China's unique hukou system of home registration, which restricts permanent migration to cities but allows a large amount of temporary migration, thereby creating a group of urban residents with restricted rights known as the "floating population”.

In this paper, we investigate a little bit closer these issues. For that, we will first expose some theoretical mechanisms behind any housing policy. In Section 2.1., we will evaluate the pros and cons of government involvement in urban housing, distinguish between the traditional approach, which considers the housing market as frictionless competitive market, and the modern approach where the housing market is characterized by frictions and imperfections. Quite naturally, the policy recommendations will be quite different, ranging from little government intervention to much more intervention and interactions between different markets. In Section 2.2, we will develop our second theoretical issue: the pros and cons of renting versus owning. The debate is relatively complicated and we will investigate the main advantages and disadvantages of homeownership.

Because housing policy in China is complex, in Section 3, we would like to see what can be learned from housing policies in other countries (especially in the United States, Europe, and Asia). We will see that different countries have different policies but that the same general trends in urban housing are common. One aspect that will retain our attention will be social housing. The latter has been an important part of housing policies, especially in Europe. For example, it culminated in England in 1979 where it represented 31 percent of the total English housing stock (Hills, 2007, p. 43). We will then examine what has worked and not worked with respect to housing policies in the US, Europe, and Asia.

Section 4 is devoted to housing policy issues and options in China. We will first explain the different housing policies implemented in China, especially the recent ones (Section 4.1) and the specificity of the hukou system as well as its consequences in the housing and labor markets (Section 4.2). In Section 4.3, we will summarize what we have learned from the theoretical mechanisms and the international experience in terms of housing policies. Finally, in Section 4.4, we will make some policy recommendations. We will first look at possible housing policies that may work and analyze what kinds of institutional arrangements can make things better. Then, we will analyze some alternative policies to public housing that can help improve access to affordable housing and reduce the spread of slums. 


\section{Some theoretical considerations}

\subsection{Pros and cons of government involvement in urban housing ${ }^{2}$}

We develop different arguments concerning the pros and cons of government involvement in housing, differentiating between the "traditional view", where the housing market is viewed as perfectly competitive, and the more "recent view" where the housing market is characterized by imperfect competition (i.e., asymmetric information, transaction costs, search costs, externalities) and non-competition (due to the thinness of both households and housing units in characteristic space, as well as mobility costs on both sides of the market, both the suppliers and demanders of housing have some market power).

\subsubsection{The traditional view}

In almost all housing policy debates, economists argue for less government intervention in the housing sector than other groups of experts. Most economists believe that markets work reasonably efficient and argue for government intervention to oil the wheels of the market mechanism. The main argument is that the principal role of government with respect to housing should be to enable housing markets to work.

There are circumstances where competitive markets will not work: natural monopoly (increasing returns to scale), externalities, and public goods. Government intervention may be justified on efficiency grounds to deal with each. The government should also intervene if equity and social justice can be achieved through the lump-sum redistribution of income.

Since natural monopoly and public goods are unimportant in the housing sector, and since housing-related externalities can be dealt with on a piecemeal basis (for example, most land use externalities are dealt with via zoning, and social capital externalities partially through the subsidization of homeownership), adherents of the classic market failure view of the role of government argue for limited government intervention in the housing market to improve efficiency, and income transfers rather than housing assistance to improve equity.

Thus, if we consider that housing is characterized by a perfect frictionless competitive market, with the exception of neighborhood externalities, housing markets appear efficient and the intervention of the government should be limited.

\footnotetext{
${ }^{2}$ I'm following here some arguments made by Arnott (2009),
} 


\subsubsection{The more recent view}

There is a more recent view based on the theory of optimal economic policy under imperfect information and frictions (see, in particular, Arnott, 1987, 1989, 2009; Wheaton, 1990; Read, 1997). The housing sector is particularly affected by these issues since transaction costs are large (in particular, search costs, moving costs, and transaction fees) and informational asymmetries are important (e.g., potential occupants are not fully aware of each housing unit's characteristics, and landlord and tenant do not know each other's traits). In the previous discussion ("the traditional view"), efficiency was achieved by correcting market failures and equity via lump-sum redistribution. However, lumpsum redistribution is feasible if the government could observe need directly, but it cannot in reality, and instead must imperfectly infer need on the basis of what it can observe. In that case, first-best policies cannot be achieved and second-best policies (when there are some unalterable constraints that preclude attainment of the first best) have to be implemented.

Since the menu of second-best redistributive policies might include housing subsidy programs, consideration of asymmetric information provides a potential basis for an expanded role of government in the housing sector, beyond correcting for the classic market failures.

More generally, if one considers the housing market as being characterized by imperfect competition and frictions resulting from search costs, mobility costs, and contractual incompleteness, then a central question is how housing markets actually achieve coordination in the absence of a Walrasian auctioneer, given all the particularities of housing (immobility, durability, heterogeneity, etc.). Stimulated by advances in the theory of imperfect information, incomplete contracts, optimal search and matching markets, this strand of research 'took off' in the eighties and has made substantial advances since then (Quigley, 1997; Hubert, 2006; Arnott, 2009). This literature deals with a broad range of issues, e.g., the role of real estate agents, the purpose of the various features of rental contracts, the function of vacancy rates, optimal pricing strategies and search behavior, etc. This approach delivers a more realistic picture of the institutions and mechanisms through which coordination is achieved and adds a cautious note with respect to the welfare properties of the housing market. Due to search and mobility cost, competition is imperfect even with a large number of agents on both sides of the market. Search externalities give rise to vacancy rates which deviate from first best, and incomplete contracts create subtle turnover externalities. Not surprisingly, the policy implications tend to be richer than under perfect competition and perfect information. In principle, efficiency can often be enhanced through appropriate state intervention, though practically the very same features which prevent the market from achieving firstbest efficiency make the desirability of government intervention moot.

So the key question in terms of the welfare economics of housing policy is what level of government that should undertake it. The standard argument, deriving from the literature on fiscal federalism, is that the central government should undertake broadbased redistributive policy since its doing so generates less welfare-induced migration and according to some standards is fairer. Contrary to this is the argument that local governments are better informed about local conditions and are better able to judge which households are the most needy. In the United States, broad-based housing 
programs are set up and funded by the central government but are administered at the local level.

Finally, much of the literature on housing policy overlooks spatial aspects. Where a household lives determines its access to public services, including education, as well as neighborhood quality. A housing program that is otherwise well designed may lead to its beneficiaries being socially isolated and having poor access to job opportunities. ${ }^{3}$ More generally, housing policy can have long-term effects on the spatial structure of cities, influencing especially the social composition of neighborhoods.

Since almost all housing market policies are targeted either on renters or on a particular class of owners, it is important for sound policy analysis to have a good understanding of tenure choice. This is what is studied in the next section.

\subsection{Pros and cons of renting versus owning}

The discussion thus far has tended to treat housing policy in the abstract. As stated above, most actual housing policies are targeted towards either renters or homeowners, and are directed at either the supply side or the demand side of the market. Governments almost everywhere favor homeownership (see Section 3 below) due to the perception that it fosters social stability, even though homeownership for the poor is highly risky, as the recent rapid rise in US sub-prime foreclosures has shown. Since the bulk of poor households are renters, redistributive housing policies should be directed primarily at the rental housing market.

Recent housing policy experience in developed countries indicates that demandside, income-related housing subsidy programs (such as housing subsidies and housing vouchers) are generally more effective in getting decent and affordable housing to the needy than public housing and other supply-side programs (Olsen, 2003). The current majority view, based on numerous empirical studies, many of which are reviewed in Olsen (2003), is that demand-side, income-related rental assistance policies are more efficient than supply-side rental assistance policies, according to a variety of criteria.

Let us now be more precise. There are two fundamental characteristics associated with homeownership that distinguish renting and owning residents. ${ }^{4}$

The first bundle of attributes is the set of property rights associated with ownership. Because homeownership received generally a favorable treatment in tax laws (both in the US, Europe and Asia), renters possess an incentive to become homeowners sooner than their economic status might indicate, which generate impacts on the household's labor supply (i.e. it increases both participation and hours worked; see e.g., Haurin et al., 1996), wealth, fertility, investment risk, and mobility. Indeed, the desire to change tenure from renting to owning requires a household to overcome mortgage lender constraints, which means that a household may change behaviors such that its rate of savings and labor force participation prior to purchasing a home (see, e.g., Brueckner, 1986; Engelhardt, 1994; Jones, 1995). Because homeowners have much of their wealth invested in housing, they generally have more investment risk (as the recent crisis has shown) due to a less diversified portfolio.

\footnotetext{
${ }^{3}$ We discuss below the literature on spatial mismatch (Kain, 1968), which explores the consequences in the labor market for ethnic minorities to be physically isolated from jobs.

${ }^{4}$ For a survey, see Dietz and Haurin (2003).
} 
Homeownership also differs fundamentally from renting in that the transaction costs associated with securing and vacating the dwelling are significantly greater (before and after the home purchase). This also implies that owners are less mobile than renters.

One of the clear consensus that emerges in this literature is that homeowners are less mobile than renting households (see, e.g. Quigley, 1997; Dietz and Haurin, 2003) ${ }^{5}$ due to higher transaction costs and because of greater ties to their neighborhood and community. This has an impact in the labor market since lower residential mobility implies more risky behavior in the labor market. For example, as we will show below for the case of Europe, if a region is not diversified in terms of jobs it offers (for example, mining in the North of England in the 1970s) and this region is strongly hit by a negative shock, then the lack of mobility of homeowners will result in high unemployment rate in this region. There is strong evidence on this issue, at least at a regional level (see, in particular, Oswald, 1999a,b). Using simple regressions, Oswald finds that a ten-point increase in homeownership produces a two-point in unemployment for the UK regions and the US states. ${ }^{6}$ He speculates that, in 1990, almost half of industrialized nations' unemployment was due to high levels of homeownership. It is difficult to postulate a causal relationship but a strong correlation does exist. In Europe, home ownership for the poor is often linked to social housing. However, as noted by Hughes and Mc Cormick (1987), this prevents even more residential mobility because owning a council house for a poor household means that it will never move since, in that case, it will lose its right and will not be able to obtain a council house in another region.

Homeownership has also been linked to urban sprawl (Brueckner, 2000) since people that move to suburbs are often whites and homeowners. This also has an impact on poverty and difficult job access for ethnic minorities since jobs tend to follow people (Hoogstra et al, 2010), which increases the distance between where ethnic minorities live and where jobs are (Kain, 1968). For example, South and Crowder (1997) find that homeownership in the US significantly reduced the likelihood of a household relocating from a distressed neighborhood. Also, African Americans have a dramatically lower ownership rate, which reflects restricted choice in the housing market (Charles and Hurst, 2002). There is agreement that the primary determinant of the spatial extension of cities is increased demand for more housing in the form of larger homes and lots (Brueckner, 2000). Since owner-occupied dwellings are generally larger and have larger lots than rental units, there is positive relationship between homeownership and urban sprawl. Urban sprawl is clearly inefficient from an economic viewpoint (Brueckner, 2000).

\section{Housing policies in the United States, Europe, and Asia}

Throughout Western Europe, as elsewhere in the world (especially the US and Asia), housing policy reflects the political ideology of the government in power. Despite considerable variations in the aims and objectives of housing policy from country to another, governments "right of center" generally tend to favor less state intervention, give only limited support to the social-rented sector, and promote owner occupation and

\footnotetext{
${ }^{5}$ The sense of causality is not clear since people with long-term horizons are more likely to choose homeownership.

${ }^{6}$ For the US, this result has been questioned. See, in particular, Green and Hendershott (2001).
} 
private landlordism. Governments to the "left of center" normally accept the need to intervene in the market, give responsibilities and funds to local authorities and non-profit housing organizations to enable them to provide affordable housing, and attempt to ensure that housing resources are distributed fairly equitably across and within tenures.

We will now expose the different housing policies implemented in the US, Europe and Asia. Having in mind the theoretical arguments of Section 2, we will try to evaluate the pros and cons of these policies.

\subsection{The US experience ${ }^{7}$}

Let us give some interesting facts about housing in the United States. America's poor are concentrated in rental housing. Among the 15.12 million poor households in America in 2005, 57.4 percent were renters and only 8.6 percent of owner-occupant households were poor (Census Bureau, 2005). Also in 2005, the median income among renter households was $\$ 27,051$ while it was $\$ 55,571$ among owner-occupant households (Census Bureau, 2005). Housing is the single largest expense in the budgets of both renters and owners. According to the Consumer Expenditure Survey for 2005, homeowners spend on average 31.9 percent of all consumer spending and 35.6 percent for renters. Renter households tend to be concentrated in central cities while owneroccupant households are more prevalent in suburbs. Despite these facts, the federal government's housing-related policies strongly favor homeowners over renters, as allocated by its allocation of financial benefits between those groups.

In this section, we will describe the two main types of housing policies implemented in the US (those targeted towards home ownership and those targeting directly low-income households) and then expose the remaining problems and challenges for the future.

\subsubsection{US housing policies}

Let us start by describing the policies encouraging homeownership. Federal, state and local governments in the United States subsidize household investment in owneroccupied housing. The portfolio of policies includes the non-taxation of imputed rents, favorable tax treatment of capital gains, local land-use restrictions, exemption of housing from means-tested social insurance programs, subsidized mortgage insurance, and the sponsorship of secondary mortgage-market enterprises (Jaffee and Quigley, 2007).

The most significant housing subsidy programs in the U.S. are funded by tax expenditures through the Internal Revenue Code. The special status of owner-occupied housing under the personal income tax is well-known: interest payments for home mortgages are deductible as personal expenses for the first and second homes of taxpayers, up to a limit of one million dollars; ad valorem property taxes on owneroccupied houses are also deductible as personal expenses; the implicit rental income from

\footnotetext{
${ }^{7}$ I cannot present all the possible housing policies in the United States; there are just too many. For an overview of these policies, see Schwartz (2006). See also Olsen (2003) and Green and Malpezzi (2003) who provide expert reviews of the current state of housing policy in the United States, as well as some of its history.
} 
occupying the house (the "dividend") is excluded from gross income; and capital gains are essentially untaxed. ${ }^{8}$

Beyond these subsidies to home ownership, which apply to all owner-occupants, the U.S. tax code provides additional subsidies to specific groups of homeowners. These programs are managed by the states, but the source of the subsidy is federal tax expenditures. The tax code permits lower levels of government to issue tax-exempt debt and to use the proceeds for the benefit of specific mortgage holders through the Mortgage Revenue Bond (MRB) program. Recipients benefit by obtaining mortgages which have been issued at the lower tax-exempt interest rate, rather than the market rate.

Let us now describe the policies directly targeting low-income households. Tax deductions of housing expenses are an important proportion of fiscal expenses in many countries. These deductions are often based on equity reasons as it is considered that they are useful to help many households to afford a house to live in. For example, in its preamble to the 1949 Housing Act, Congress declared its goal of "a decent home in a suitable living environment for every American family." In the more than 50 years since this legislation was passed, the federal government has helped fund the construction and rehabilitation of more than 5 million housing units for low-income households and provided rental vouchers to nearly 2 million additional families (Schwartz, 2006). Yet, the nation's housing problems remain acute. In 2003, 46 million households lived in physically deficient housing, spent 30 percent or more of their income on housing, or were homeless (National Low Income Housing Coalition, 2005)

Excluding tax expenditures, the federal government provides subsidies for lowincome households in three basic ways: (i) supporting the construction and operation of specific housing developments; (ii) helping renters pay for privately owned housing; and (iii) providing states and localities with funds to develop their housing programs. ${ }^{9}$

(i) Supporting the construction and operation of specific housing developments: These policies are known as supply-side or project based subsidies and include public housing and several other programs, such as Section 8 New Construction, in which the federal government helps subsidize the construction and sometimes the operation privately owned low-income housing. The aim is to "remedy the acute shortage" of decent housing through a federally financed construction program that sought to eliminate "substandard and other inadequate housing." The low-income housing tax credit (LIHTC) program was authorized by the Tax Reform Act of 1986 to provide direct subsidies for the construction or acquisition of new or substantially rehabilitated rental housing for occupancy by lower-income households. Through 2003, the tax credit has helped fund the development of more than 1.2 million housing units.

(ii) Helping renters pay for privately owned housing: This has become the dominant form of low-income housing assistance. The government provides low-income households with vouchers. Households in possession of vouchers receive the difference between the fair market rent in a locality - the median rent, estimated regularly for each metropolitan area by the Department of Housing and Urban Development (HUD) —and 30 percent of their income. Households in possession of a voucher may choose to pay

\footnotetext{
8 Many other developed countries also provide preferential treatment of homeownership through their systems of national taxation (see Englund, 2003, for an international comparison, and the next sections).

${ }^{9}$ For an overview and historical perspectives of the programs, see Jafee and Quigley (2007).
} 
more than the fair market rent for any particular dwelling, up to 40 percent of their income, making up the difference themselves. They may also pocket the difference if they can rent a HUD approved dwelling for less than the fair market rent.

(iii) Providing states and localities with funds to develop their housing programs: These policies consist of block grants that fund housing programs crafted by state and local governments. States and localities usually receive block grants on a formula basis and have the latitude to use the funds for a wide range of purposes. The oldest and largest block grant program, the Community Development Block Grants (CDBG) gives states and localities the most discretion in determining how funds may be used.

\subsubsection{Major unsolved issues and challenges for the future}

Even though the United States has spent millions of dollars on housing policy, three major issues are still unsolved (Retsinas and Belsky, 2008):

(1) The incomes of millions of American households are too low for them to pay for adequate rental shelter. They have to devote so much of their incomes to housing that they cannot afford other necessities, such as health care, transportation, education and food. Here two problems can be identified: Wages of low-skill workers are too low and/or housing prices are too high. Direct subsidies (either in terms of wages or housing) for poor renters could be implemented to solve this issue but would cost a lot of money, which is very unlikely given the present situation.

(2) Federal housing-related policies are mainly based upon the political popularity of homeownership and not upon the intensity of housing needs among households, even though it is renter households that need housing assistance most acutely. In theory, the government could change its policy and spend more money on renters than home ownership. As Quigley (2008) suggested, money directed to high-income homeownership could be directed to housing vouchers and other subsidies for renter households.

(3) Areas of high poverty, crime, drug abuse, unemployment, etc. combine lowquality public schools and lack of health care that make living in such areas very difficult and much more harmful than living in most-middle income neighborhoods. Moreover, most American suburbs are politically dominated by home-owning majorities, who pressure local governments to maintain regulatory barriers against local construction of low-cost single family homes or any rental apartments at all. This makes difficult for low-income households to move out concentrated poverty areas into richer suburbs, where they could easily obtain good jobs and good schools for their children (literature on spatial mismatch, urban blight, etc.). This is a major blow of the housing policy in the United States. We have discussed some of these issues in Section 2.2.

Some policies have tried to address these problems but with limited success. Let us describe them.

An interesting policy aiming at fighting against poverty has been implemented in the US since the 1960's and is called the Moving to Opportunity (MTO) Program. Its aim is to promote the chances in life for young people in segregated areas. The programs have been implemented in large cities like Boston, Chicago, Los Angeles and New York and mean that families in areas with high unemployment and poverty are given the possibility of moving to areas with a higher level of gainful employment and education as well as 
better schools and education. The program is optional and covers families that live in an area where more than 40 percent of the population are defined as poor. The government covers the additional cost that emerges when the family is to change from cheaper to more expensive housing. The results of most MTO programs (in particular for Baltimore, Boston, Chicago, Los Angeles and New York) show a clear improvement in the wellbeing of participants and a reduction in criminality but have little effect on education and employment (see, in particular, Ladd and Ludwig, 2001; Katz et al., 2001; Ludwig, et., 2001; Rosenbaum and Harris, 2001; Kling and Katz, 2005). One interesting argument advanced by Quigley and Raphael (2008) is that the effects on education and employment are small because the MTO programs move people (mainly blacks) from very poor areas to poor areas. In particular, the treatment (that is, the exposure to new neighborhoods) falls far short of moving experimental subjects to neighborhoods comparable to those of the average poor white resident in metropolitan areas.

Another interesting policy implemented in the United States (but also in the UK and France; see Zenou, 2009a) is the "Enterprise Zone" (EZ) program, which aim is to revitalize depressed local areas by tempting firms to become established in segregated areas. Politicians identify all depressed areas with certain characteristics such as: high unemployment, considerable poverty, a high level of criminality, a large number of young people without education. All firms that become established in these areas are exempt from tax (pay-rolls taxes) during a certain period (typically five years). The idea of this policy is to decrease the "distance" (both physical and social) between people living in these areas and firms by helping them enter the labor market. In return, each firm must hire a certain fraction of their employees from the local population (this varies from state to state). The effects of this policy on employment are mixed and rather small (see e.g., Papke, 1994; Boarnet and Bogart, 1996; Bondonio and Engberg, 2000, 2007; Busso and Kline, 2009; for a review, see Peters and Fisher, 2002).

As stated above, programs like the MTO and EZ have had only small effects. The key question is whether we should help people to move out poor areas (such as in MTO programs) or should we, on the contrary, improve poor neighborhoods (such as the EZ programs). ${ }^{10}$ In other words, do we want people-oriented or place-oriented policies? There is no simple answer but we believe that these two types of policies are complementary and should implement together.

Finally, because it is difficult for minorities to live in the suburbs, Katz and Turner (2008) have suggested that the federal government should create substantial financial incentives for state government to pressure local governments to reduce barriers to more affordable housing, especially in the suburbs. ${ }^{11}$ But this has been done in the past without success. The problem is much more complex and it is not sure that housing policies by themselves could solve this very complicated issue. Combined housing and labor policies such as the Enterprise zone program could be effective if implemented correctly. We will further discuss these issues in Section 4 below.

\footnotetext{
${ }^{10}$ As noted by Rosenthal (2008), a fundamental difference between now-construction and voucher-type programs is their effect on where the poor can live. With public housing and Low Income Housing Tax Credit (LIHTC) programs, an important fraction of the low-income housing stock will be found within a city and these programs will tend to concentrate the poor. By definition, voucher-type policies do the opposite since they help households to leave poor neighborhoods and usually to move in the suburbs.

${ }^{11}$ Some of this gets mixed up with local tax policy.
} 


\subsection{The European experience}

Contrary to the United States, there is no common housing policy at the European (federal) level since, formally, the European Union (EU) is not legally empowered to make housing policy; competence in the area of housing policy is held by individual member states. ${ }^{12}$ In most European countries, however, there is a mixture of many interventions, but three pillars of housing policies in Europe can be put forward: (i) promote home ownership, (ii) construction of public housing, (iii) direct rental subsidies to households, especially low-income households. In some sense, these policies are relatively similar to those implemented in the United States (see Section 3.1).

\subsubsection{Housing policies in Europe ${ }^{13}$}

\section{(i) Home ownership}

This is the most popular housing policy that has been implemented in Europe for the last decades. There are, however, very large differences between countries. ${ }^{14}$ For example, Ireland, Spain, and the United Kingdom are a very diverse group of countries demographically, economically, socially, politically, but, in each of these countries, and for different reasons, owner occupations is the dominant tenure. ${ }^{15}$ Interestingly, the US home ownership sector is relatively smaller than that some European countries like Ireland, Spain, and the United Kingdom but much larger than Hungary for example (Scanlon and Whitehead, 2004). If we, for example, compare France and the US, then one can see that homeownership is more developed in the US where $68 \%$ of households own their dwellings, versus $56 \%$ in France (in 2001). Perhaps more importantly, the proportion of mortgage holders among owners is also much higher (62\%) in the US, than in France (38 \%). ${ }^{16}$ In most of the European countries, owner-occupied housing as been vigorously promoted by government through the provision of subsidies and mortgage-tax reliefs.

(ii) Public and social housing

Public and social housing are a much more important part of the European housing policies, with council housing in the UK, HLM in France, etc. There are also very large variations between European countries. The social rented housing stock is proportionally larger in the Netherlands, Sweden and Austria than in the EU in aggregate. Although in France the sector is marginally smaller than the EU average, the social

\footnotetext{
12 Interestingly, there is a relatively recently published report (November 2004), called the Kok report (after Wim Kok, former Prime Minister of the Netherlands), which focuses on growth of economies and jobs in the EU, that contains statements about desirable housing outcomes. This report promotes a Europe with higher levels of home ownership and also higher levels of private renting with reduced levels of social housing (Doling, 2006).

${ }^{13}$ A good overview of the housing policy in Europe can be found in Bachin (1996)

${ }^{14}$ See, in particular, Englund (2003) for a comparison of homeownership and taxes between different countries in Europe.

${ }^{15}$ For example, programs like "Mortgage Tax Relief" and "Right to Buy" in the UK (Gibb and Whitehead, 2007) are typical programs promoting home ownership.

${ }^{16}$ See Table 10.1 in Laferrère and Le Blanc (2006).
} 
rented stock has experienced substantial growth in recent years as a result of proactive governmental and institutional policy. If we look at the different European countries, which differ considerably in term of size and demography, and in their economic, social and political backgrounds, we can observe that each country has experienced serious housing shortages after the Second World War, and each to a significant extent has looked to the social-rented sector to satisfy its housing needs. ${ }^{17}$

While the Netherlands has the largest proportion of social rented housing in the EU, 36 percent in 1994 compared to an EU average of 18 percent (Balchin, 1996), in Spain it is quasi non-existent. Spain is a typical example of a European country where government policies have favored home ownership at the expense of social housing. This has totally changed the picture of housing in this country (Eastaway and Varo, 2002). In 1950, the percentage of dwellings to be rented was higher than the one representing houses in ownership (see Table 1). However, the sharp downward trend in the rental sector jointly with the upward evolution of owner-occupation had completely changed the scene at the end of the 1990s.

Table 1. Tenure patterns of main residences in Spain, 1950-95 (percentages)

\begin{tabular}{|c|c|c|c|c|c|c|}
\hline & 1950 & 1960 & 1970 & 1980 & 1990 & 1995 \\
\hline Social rented housing & 3 & 2 & 2 & 2 & 1 & 1 \\
\hline $\begin{array}{c}\text { Private rented } \\
\text { housing }\end{array}$ & 51 & 43 & 30 & 21 & 15 & 13 \\
\hline Total rented housing & 54 & 45 & 32 & 23 & 16 & 14 \\
\hline Owner-occupation & 46 & 51 & 64 & 73 & 78 & 81 \\
\hline Others & 0 & 4 & 4 & 4 & 6 & 5 \\
\hline Total & 100 & 100 & 100 & 100 & 100 & 100 \\
\hline
\end{tabular}

Source: Eastaway and Varo (2002)

(iii) Direct rental subsidies to low-income households

Housing consumption and investment remain subsidized even in the most liberal countries. In 2001 the US spent $1.54 \%$ of GDP, and France $1.74 \%$ on public aid to housing (Laferrère and Le Blanc, 2006). Overall, in France in 2000, the amount spent on housing subsidies to private sector tenants was 5.3 billion Euros (Laferrère and Le Blanc, 2004). This is by no account a small figure. In January 1992, a law passed in France which extended rental assistance to all low-income households, including students. The subsidy is thus a universal means-tested allowance. There were 1.9 million assisted private sector tenants in 1990, which represented a third of all private sector tenants and 3.1 million in 1997, representing half of private sector tenants (Laferrère and Le Blanc, 2004). The proportion of assisted tenants is large, compared to most countries. In the US, housing allowances have been available for low-income private sector tenants since 1974 . Some $13 \%$ of American renters are assisted and about half of them get an allowance close to the French type (the so-called Section 8 certificates and vouchers). The main

\footnotetext{
${ }^{17}$ Whereas housing subsidies normally involve transfer payments from tax payers to the producers or consumers of housing, rent control results in a transfer of payment from landlords to tenants representing the difference between market rents and controlled rents, and is thus also a subsidy. Social housing is typically a rent control.
} 
difference is that while all French eligible households receive an allowance, there exist quotas of vouchers in the US, and it is estimated that only a third of eligible households receive them (Olsen, 2003). In other words, in the French system, housing subsidies are an entitlement. Even if we have focused on France, most European countries have similar policies in terms of subsidizing housing to low-income households.

\subsubsection{Evaluation of housing policies in Europe}

Let us evaluate the different housing policies in Europe. We have seen that there is a large home ownership sector in European countries, often larger than that of the US in many countries.

The first problem is that home ownership has been encouraged by the different European government at the expense of social renting so that there has been an increased degree of polarization between owner-occupation and social renting (see, e.g. Table 1 above for Spain). The problem of how to deal with the more deprived components of housing demand has remained largely unsolved. As a result, poverty and deprived areas have increased over time and has become a real problem in Europe, especially with the large influx of immigrants in the last three decades who tend to live in segregated areas (Bisin et al., 2009). The private-rented stock, meanwhile, has also decreased in scale (in part because of rent control but also through unfavorable tax treatment and investment returns).

The second problem is that homeownership is not always good for the economy. As stated in Section 2.2, Oswald (1999a, 1999b) has identified a significant statistical correlation between rates of home ownership and rates of unemployment in economically advanced countries. In commenting on this, Oswald asserted that there was a causal mechanism - higher rates of home ownership increased unemployment rates that occurred because home owners are relatively immobile. There are two main components of this. The first is transaction costs, which vary widely from one European country to another, but in general are considerable, running to thousands and in some cases tens of thousands of Euros (Coogan, 1998). Oswald recognized a second possible curb on the mobility of home owners, that immobility could be the result of the high costs of housing, relative to incomes, making it difficult for people, particularly young and unemployed, to move away from the parental home.

Like home ownership, social housing is not good for labor mobility. Critics of rent controls (or social housing) argue that it leads to a sub-optimal use of dwellings and reduces the mobility of labor. Indeed, an important aspect of the social provision of housing is that the output is allocated to households by administrative rather than market mechanisms. As a result, much of the literature relating mobility to tenure has tended to identify the bureaucratic procedures of social housing and rent control as being the major cause of inertia in the housing market (see Minford et al., 1987; Hughes and McCormick, 1987, 1990). In particular, Hughes and McCormick (1987, 1990) have examined migration behavior and compared outcomes between council tenants and equivalent owner-occupiers in the US and the UK. They show that council house tenants tend to migrate less often than those in the market sector and when they do move it is likely to be 
for housing rather than labor-market reasons. ${ }^{18}$ More generally, administrative allocation, rent controls and subsidies to owner occupation are all shown adversely affect the operation of the labor market (Bover et al., 1989).

Other researchers have stressed the advantages of private rental housing in providing easy and quick access, leading to the suggestion that more renting and less ownership would, from an economic growth perspective, be a preferred option.

In sum, in view of the potential importance of the rental sector for labor mobility and for the efficient, overall functioning of the housing market, the bias of tax relief and subsidies in favor of owner-occupation should be re-considered in Europe, particularly in countries where the share of the rental sector has fallen to very low levels (see Table 2)

Table 2. Housing in Europe

\begin{tabular}{|c|c|c|c|c|c|}
\hline & & & \multicolumn{2}{|c|}{ Rent } \\
\hline & $\begin{array}{c}\text { Housing } \\
\text { stock } \\
\text { (millions) }\end{array}$ & $\begin{array}{c}\text { Owner- } \\
\text { occupation } \\
\text { (percentage) }\end{array}$ & $\begin{array}{c}\text { Rent } \\
\text { (percentage) }\end{array}$ & $\begin{array}{c}\text { Private } \\
\text { (percentage) }\end{array}$ & $\begin{array}{c}\text { Public } \\
\text { (percentage) }\end{array}$ \\
\hline Germany & 35.55 & 42 & 58 & 83 & 17 \\
\hline Denmark & 2.43 & 50 & 44 & 42 & 41 \\
\hline France & 27.81 & 54 & 39 & 52 & 44 \\
\hline Italy & 25.03 & 79 & 18 & 70 & 23 \\
\hline UK & 23.71 & 65 & 35 & 29 & 71 \\
\hline Spain & 18.26 & 78 & 14 & 92 & 8 \\
\hline
\end{tabular}

Source: European Commission (1998)

There are, however, important differences between the European and American housing policies. As noted by Whitehead (1999), in Europe, housing has been seen as a fundamental part of national social policy while, in the United States, most housing policies (for example, rent control, dwelling-based taxation, housing assistance to lowincome families, zoning, etc.) are fundamentally local policies. As a result, evaluating European policies can be done by comparing different country experiences while, in the US, comparison across areas is more relevant.

\subsection{The Asian experience ${ }^{19}$}

While Singapore is not generally regarded as a welfare state, the provision of housing welfare on a large scale has been a defining feature of its welfare system. The extensive housing system has played a useful role in raising savings and homeownership rates as well as contributing to sustained economic growth. Few would dispute the description of Singapore's housing policies as "phenomenally successful" (Ramesh, 2003). Singapore's economic growth record in the past four decades has brought it from

\footnotetext{
${ }^{18}$ The social housing sector has been developed in England in the 1960s and 1970s where it peaked at 31 percent of the total English housing stock in 1979 (Hills, 2007, p. 43). After this period, social housing has declined in England because of the "right-to-buy" scheme introduced by Margaret Thatcher in 1986 and the public spending cuts on new constructions (Hills, 2007) to reach 18.5 percent of the stock in 2004.

${ }^{19}$ An overview can be found in Groves et al. (2007).
} 
third world to first world status, with home-ownership widespread at more than 90 percent for the resident population. Singapore has 4.2 million people and a land area of only 697 square kilometers. While housing loans per GDP constituted 4 percent in 1970 it reached 64 percent in 2000 (Phang, 2007). As in most countries, there were different phases in the post-war housing policies: (1) Building shortages (1947-1979); (2) Deregulation and creation of resale market (1979-1990); (3) Financial liberalization and housing price inflation; (4) Excess housing stock (1998-present). ${ }^{20}$ To summarize, Singapore policy relies on compulsory savings, state-land ownership, and state provision of housing and an extensive public sector.

Hong Kong has a total land area of 1,097 square kilometres, among which 83 percent is non built up land and only 5.3 percent is residential built up area. Social housing has provided a safety net for the poor in Hong Kong. It combines this with clearance of illegal squatter huts. Two main policies: (1) Housing Subsidy Policy (HSP) (introduced in 1987 and revised in 1993) and the Safeguarding the Rational Allocation of Public Housing Resources (SRA) policy (implemented in 1997 and revised in 1999), and (2) the Comprehensive Means Test (CMT) policy, which deals with all the prospective tenants of public rental housing. Without the involvement of the Hong Kong Housing Authority (HKHA) in the redevelopment process of older public rental housing estates, the improvement in housing conditions, landscape and spatial distribution of modern housing estates would have been impossible.

Even if social housing policies have worked relatively well in Singapore and Hong Kong, their applicability to China is difficult because of the very specificity of these countries in terms size, population, etc. As a result, we will now look at larger Asian countries, more similar to China.

Since 1998, when south Korea ${ }^{21}$ was seriously affected by the Asian economic crisis, the Korean government has put special emphasis on the social safety net because of a great increase in poverty and unemployment. In its housing policy in 2002, the Korean government for the first time established the Construction Plan for One Million Rental Housing Units from 2003-2012. The aim was to ensure a supply of good quality affordable rented housing for low-income families. Additionally, in 2004, the Korean government establish the Korea Housing Finance Corporation to promote home ownership for low- and middle-income families by providing long term mortgages. ${ }^{22}$

The main pillar of housing policy in Japan $^{23}$ is to encourage the building of owner-occupied housing by means of GHLC (Government Housing Loan Corporation) loans. The interest rates on the subsidized loans are 2 to 3 percent lower than the market mortgage rate (Kanemoto, 1997). The amounts of subsidies involved in the GHLC loans are quite sizable. The GHLC loans are available also for rental housing construction, but subsidies involved are much smaller. The GHLC loans therefore favor owner-occupied housing over rental housing. National government expenditures on housing programs are

\footnotetext{
${ }^{20}$ A major distinct characteristic of Singapore is the availability of retirement savings for private housing finance through Central Provident Fund (CPF).

${ }^{21}$ The population of South Korea in 2000 was 46 million inhabitants. Home ownership decreases from 71.7 percent in 1970 to 54.2 percent in 2000 (see Park, 2007).

22 To develop and improve poor areas, different housing regeneration programs have been implemented in South Korea (Ha, 2007).

${ }^{23}$ The population of Japan was 127,716 million in 2004, its land area, $377,899 \mathrm{~km}^{2}$, and its home ownership constituted 61.2 percent in 2003 while private rented houses: 26.8 percent in 2003 (see Hirayama, 2007)
} 
$1.4 \%$ of the total budget of the Japanese national government in 1993. This is close to that of the U.S. but lower than those of the U.K. and France and higher than that of Germany (see Table 10 in Kanemoto, 1997). ${ }^{24}$

The Japanese housing system, which concentrated public funds on middle-class families and encouraged them to purchase their own homes, generated a large disparity between those on low incomes and those with higher incomes; between single and family households; and between renters and home-owners. The government has neglected public housing. It is a two-tiered system where there has been generous support for middle-class groups on one tier, support for those on lower incomes has become increasingly residualized and the target group for the direct provision of public housing has been strictly limited on the second tier. The government created a system that defined homeownership as the social norm and placed public housing provision as a marginal measure.

The housing sector in India ${ }^{25}$ for several decades faced a number of set-backs, such as an unorganized market, development disparities, a compartmentalized development approach and a deterrent rent control system. There was not even a concerted attempt to understand the housing problem let alone promote it.

The Government of India adopted a central planning model of development. The Planning Commission of India is the central think tank which prepares the five year plans. These plans give a broad direction regarding the policy of the Government of India. They also give the broad allocation of financial resources to various sectors of the economy. Based on the five year plans, annual plans are prepared by state governments for implementation. A look at the five year plans reveals the manner in which the Government of India had perceived the housing sector in the initial years and the manner in which it sees it now. Financial allocation for housing as a percentage of the total investment in the economy was as high as 34 percent in the First Five Year Plan (195156) but has now come down to as low as 2.4 percent in the Tenth Five Year Plan (20022007). As part of the Five Year Plans, the Government of India had launched various programs for providing housing to the people.

The post 1990 period can be seen as the era of housing sector reforms. These reforms have overturned the situation to a great extent. The designing of a shelter policy, the organization of the housing finance market, the introduction of fiscal incentives, increased public investment, legal reforms and others initiatives have brought about a number of changes in the housing sector (Mahadeva, 2006). Interestingly, these changes have been concerned with both reducing the housing shortage and increasing the number of quality housing stock besides increased access to various other housing amenities like safe drinking water, good sanitation and household electricity. But, at the same time, since these measures are in the process of taking roots and are in their infancy stages, the number of houseless people looking towards the state's help are increasing, especially in backward and rural areas. Most social housing schemes, which have been in vogue for over 50 years, have yet to address the housing and amenities needs of the vulnerable groups. In the year 1981, there were 28 million slum dwellers in Indian cities and this number rose to 45 million by the year 1991 . The number of slum dwellers in the year 2001 was still at 40 million. As a percent of the urban population, the figures increased

\footnotetext{
${ }^{24}$ The Japanese subsidy programs are mainly financed through national taxes on firms (Seko, 1994).

${ }^{25}$ India's population is approximately 1.17 billion people (estimate for July, 2009) and consists of approximately onesixth of the world's population.
} 
from 17.5 percent in 1981 to 21.5 in 1991 and 22.8 in the year 2001 (Government of India, 1997, National Buildings Organisation, 2003)

To summarize, it seems that in Asia, especially "large" countries, a lot of emphasize has been put on homeownership at the expense of social housing and aid to poor households. Because of the different crises in Asia, this has created a poor population that has been neglected by government policies, especially housing. While Korea and India have tried to implement some social policies, Japan has mostly focused on middle- and high-income households, leaving behind the poor families. As a result, as in Europe, poverty and depressed areas have sharply increased in the last decade, especially after the financial crisis in 1998.

\section{Policy issues and some options for Chinese policy makers}

We would now like to draw some policy recommendations for housing in China based on the theoretical mechanisms highlighted in Section 2 and on the international experiences exposed in Section 3. Let us first describe the salient features of the housing policy in China.

\subsection{Housing policy in China}

Before 1949, most urban housing was private rental, provided by landlords. This was changed through a socialist transformation in the 1950s, in which the majority of properties owned by big landlords where nationalized. Public housing were built by government owned enterprises and institutions (work units) and distributed directly to their employees as part of a comprehensive welfare provision system. Other elements in this welfare system include free education, health care, and pensions.

The first important housing reforms were implemented in the 1980s where a public housing provision system was established in all cities and large towns. The housing reforms resumed in the early 1990s where house building was carried out by commercial developers rather than public sector employees. Housing privatization was a main element of these reform programs. By 2002, 80 percent of public housing has been sold to its occupiers. The socialist system of public housing and welfare support (supporting the idea of a universal housing benefit system provided through public sector employers) has given way progressively to a new system, which is market based and supports home-ownership (Lee, 2000). To be more precise, this new, marked-based system focuses on two main areas: (i) support for home ownership for the middle- and high-income families through financial arrangements (i.e. housing provident fund system, mortgage finance, building affordable housing, and housing subsidy); (ii) support for low-income households through a remodelled social housing provision system.

Indeed, with the introduction of the market economy, welfare services provided by employers were substantially reduced in order to improve production efficiency. Also, because of the market economy system, house prices started to soar in cities and the gap 
between the rich and the poor widened, especially in cities. The housing policies introduced in 1998 envisaged that about 5 percent of low-income urban families would rent social housing (lianzu fang) from the municipal government. However, its development was very slowly and by 2003, only few provinces had produced local regulations for social housing. Furthermore, in most cities that implemented this policy, fewer than five percent of households actually received some help. ${ }^{26}$ One of the requirements for having access to social housing was that at least one member of the households must have local permanent non-agricultural hukou registration for more than five years. $^{27}$

Subsidized rental housing was seen by many local officials as a temporary measure to solve a short-run problem. However, with increasing unemployment and lack of social insurance, poverty became an issue and the number of households who actually need help was increasing rather than decreasing. In particular, a large fraction of poor living in cities are migrants who do not hold a hukou, and have thus almost no access to formal sector housing market (which is intended to be $100 \%$ owner occupied), for a whole variety of reasons including no access to mortgages. As a result, migrants in cities mainly rent in the informal sector.

The housing reform has led to the fact that the urban poor (most of them illegal migrants) have been marginalized into poor areas and locations while the rich and new middle class have emerged as the key players in the housing market.

Although home-ownership and asset building is certainly a better approach than the socialist welfare provision, new problems have emerged, especially with the relative increase of the urban poor in cities. ${ }^{28}$ Also, because housing building in the last ten years has been dominated by commercial property developers, new housing estates were built on different standards. This practice results in serious spatial segregation between the new and the old buildings, ${ }^{29}$ and between the rich and the poor.

Before proposing some recommendations that could alleviate poverty and segregation in China, we would like to expose one of the specificities of China: ruralurban migration and the policies that have tried to limit this migration. This is unique to China.

\footnotetext{
${ }^{26}$ In fact, most social housing has been sold rather than rented and often sold to non-poor households (i.e. typically above average incomes).

${ }^{27}$ Unlike most countries, China regulates internal migration. Public benefits, access to good quality housing, schools, health care, and attractive employment opportunities are available only to those who have a local "Household Registration System," also called "Hukou”. Instituted in 1958, Hukou requires every citizen seeking a change in residence to obtain permission from the public security bureau. Hukou is effectively an internal passport system that makes the process of moving between or within provinces analogous to the process of moving between countries. Coincident with the deepening of economic reforms, Hukou has gradually been relaxed since the 1980s, helping to explain an extraordinary surge of migration within China. We explain in more detail the hukou system and its consequences in the next section.

${ }^{28}$ This increase is relative since, using the World Bank poverty line, income poverty rate in China of migrants is 5.4 percent, urban residents 0.2 percent, and rural residents 10 percent. Furthermore, China has pulled about half a billion people out of poverty over past 25 years.

${ }^{29}$ Of course "old buildings" may be in potentially lovely heritage parts of the city that the Chinese government is anxious to tear down to "modernize" rather than gentrify the private market.
} 


\subsection{Rural-urban migration and the very specificity of the hukou system}

China's very fast urbanization has induced a massive rural-urban migration since the late 1970s. According to official estimates, at the end of 2000, there were about 70 million rural-urban migrants working and living in urban areas. ${ }^{30}$ About 63 percent of rural migrants are employed in industry, construction, and service sectors in urban area, with the majority of them being self-employed or employed by privately owned enterprises (Chan et al., 1999; Liu et al., 2003).

Despite reduced constraints on rural labor mobility since the late 1970s and recent improvements in supporting institutional arrangements on migration control, rural migrants still encounter great difficulties in acquiring urban registration (urban hukou) and permanent residence status in urban areas (Wang and Zuo, 1999). Due to the incompleteness of the urban social service system reform, nearly all of those migrants are considered as being temporary in urban areas and thus do not have access to many urban amenities. For example, it remains still difficult for rural migrants to access urban housing (Chan and Zhang, 1999; Zhang et al., 2003; Wu 2004). Zhang et al. (2003) and Wu (2004) summarize the main sources of rural migrants' difficulties in accessing urban housing. First, as we have seen in Section 4.1, the restructuring of the urban housing market since the reform is orientated to privatization and commercialization of housing (Song et al., 2005). Therefore, newly emerged units of commercial housing, built essentially for making profit by real estate developers, are generally expensive and thus not affordable to migrants who are employed in low-paid jobs. Second, more affordable units provided by the secondary housing market where transactions of older housing units occur, or by subsidized public housing programs for the low-income families (known as the anju project) require a local urban hukou and are thus not available to rural migrants. As a result, scholars have concluded that recent reforms in urban housing provision overlooked the needs of rural migrants who are constrained by their low purchasing power and lack of urban hukou.

Excluded from the urban housing system, many of the rural migrants reside in the urban villages where native farmers construct and rent out inexpensive housing units (Song et al., 2008). Through these villages, indigenous farmers are becoming well-off landlords by building extra rooms (Mobrand, 2006) and rural migrants are thus able to find shelter. Nonetheless, villages within cities are generally perceived as undesirable and consequently dispelled by urban authorities because of the villages' association with unplanned land uses, decayed housing condition, worsened public safety, and deteriorated social order. Urban policies have been therefore adopted to demolish villages within cities and to redevelop them into commercialized housing districts. Neglecting millions of rural migrants residing urban villages, the debate on the adequate policies that should be adopted to redevelop the villages has been kept between urban authorities and the indigenous peasants who build the villages.

\footnotetext{
${ }^{30}$ This number is now closer to 150 million (in 2010).
} 


\subsection{Lessons from theory and international experience}

Let us summarize what we have learned so far in terms of policies.

\section{(1) Should the government intervene in housing?}

The answer is clearly yes. Because of transaction costs and frictions, the housing market is clearly imperfect and no "invisible hand" will be able to restore efficiency through the market. In particular, the fact that poverty and segregation are rampant in most countries, including China, show that the housing market is not functioning well and the government (at the local and/or national level) should intervene to correct these imperfections. One has to be, however, careful with the types of interventions the government can implement. The main issue is what incentives and education/information do governments need in order to intervene in a way that promotes greater equity and efficiency. In particular, local governments in China have no incentives to invest in human capital and reduce poverty since they are mainly evaluated on FDI, economic growth, physical capital, etc.

\section{(2) Should homeownership be encouraged?}

We have seen that policies encouraging homeownership (as in the US and Asia, and to some extent in Europe) mainly favor middle- and high-income families, often at the expense of poor families. We have also seen that the two main drawbacks of such a policy is that (i) it makes households more vulnerable to financial crises (such as the recent one), especially homeowners belonging to lower-income classes, because of the lack of diversity of their assets and (ii) it renders homeowners less mobile and therefore makes them more vulnerable to economic shocks and more likely to be unemployed. There are of course positive aspects of homeownership such as savings incentives, positive externalities, social capital, etc. (Dietz and Haurin, 2003). It would seem, however, that the issue for urban China is to encourage, or permit a formal sector rental market. Right now renting in the formal sector is taxed and has been in some cities “illegal”.

\section{(3) Should more social housing be developed?}

We have seen that there has been some tradeoff between homeownership and social housing. In particular, countries (like e.g. Spain, Japan, and even China) that have subsidized homeownership tend to have neglected social housing. Social housing can be a good thing because it helps poor households live in cheap but decent housing and still have enough money left to spend on health and education. It has, however, two main drawbacks. First, it induced segregation and distance to jobs. Indeed, by putting together relatively poor families in areas generally located far away from jobs (this is true both in the US and in Europe), it reduces job opportunities for these households. These areas eventually become depressed and characterized by a large fraction of ethnic minorities, poor quality of school, high unemployment rates and high level of crime. The large empirical literature on spatial mismatch (Kain, 1968; Ihlanfeldt and Sjoquist, 1998; 
Ihlanfeldt, 2006; Zenou, 2009b) has shown that: (a) poor job access indeed worsens labor-market outcomes, (b) black and Hispanic workers have worse access to jobs than white workers, and (c) racial differences in job access can explain between one-third and one-half of racial differences in employment. Second, it reduces mobility since the entitlement of a social house located in a specific area is in general not transferrable to other areas.

\section{(4) Should the government directly subsidize poor households?}

Programs such as the Moving to Opportunity (MTO) implemented in the United States (see Section 3.1.2), which give housing vouchers to families that move from poor to richer areas, are directly targeted to poor families. The main advantage of such programs is that it reduced criminality and tends to give more opportunities to people. We have also seen that the effects on employment and education are rather small because these programs move people from very poor areas to poor areas. So to be successful these types of programs need either to move people from very poor areas to much richer areas and/or to be accompanied by other programs that revitalize poor areas, especially in rural areas. Regeneration policies or enterprise (empowerment) zone programs (both implemented in the US and in Europe) could be a good complementary solution to the MTO.

\section{(5) Are they alternative policies to housing that can help improve access to affordable housing and reduce the spread of slums?}

As stated above, we believe that regeneration policies or enterprise (empowerment) zone programs could be a good alternative policy to reduce poverty and the spread of depressed areas (see Section 3.1.2). MTO and EZ programs are complementary policies since the former is a people-oriented policy while the later is place-oriented policy.

\subsection{Some options for China}

Can we apply these general principles (exposed in Section 4.3) to policy reforms in China? It is clear that some general lessons can be drawn from the theories and the international experiences of other countries in terms of housing policies. However, as we have seen, China is very special country. In particular, (i) China has experienced very important changes in housing policies switching from a very centralized and planned policy to a much more market oriented one; (ii) China has a unique migration control with the hukou system; (iii) Although China has experienced a very fast and large urbanization in the recent years, it is still under-urbanized and under-agglomerated ( $\mathrm{Au}$ and Henderson, 2006a,b); (iv) China has a relative important informal housing rental sector because of urban villages in cities; (v) China is concerned about how best to address the problem of poverty and poor housing for migrant workers in urban areas.

Here are different options that can be given based on what we have learned and the specificity of China. 


\section{(1) How should China fight against poverty in cities?}

One of the main concerns in Chinese cities is how best to address the problem of poverty mainly of "illegal" migrants (who are Chinese rural residents) living in "urban villages". Furthermore, some local urban hukou holders are also poor-- the lost generation in particular. We propose two steps to fight against this poverty. The first one is to require that the Chinese government recognizes these "illegal" migrants by helping them becoming "legal". It is indeed difficult to implement a social housing policy fighting against poverty if the government does not identify and recognize who are the poor. Second, social housing is mostly about subsidizing housing for the poor. To fight against poverty, one can either implement place-targeted policies (like the enterprise zone programs in the US and Europe and/or housing projects in the US, council housing in the UK, HLM in France, etc.) or people-targeted policies (like the MTO programs in the US).

For China, place-targeted policies would mean revitalize urban villages (the government either invests directly in renovating and modernizing buildings in urban villages or induce firms to establish there by waiving their taxes) while people-targeted policies would imply to move poor people (both illegal migrants and poor local urban hukou holders) from urban villages and/or poor areas to richer areas by paying the difference in housing prices (like the MTO programs in the US). Of course, place-targeted policies and people-targeted policies are not exclusive and can be implemented together.

One has to be, however, careful with these policies as other questions arise. Indeed, if the Chinese government integrates urban villages into city administration, then what will be the fate of housing there and the owners (original rural hukou holders in those villages). Will the government pay off those owners, tear down the housing (for villages on prime land)? In that case, they would need a person-based approach (i.e. people-targeted policies). Also for urban villages on the city fringes, is it upgrading housing that prevails?

\section{(2) Should China subsidize housing in cities? Should China encourage social housing and see it as a long-term solution?}

Because of the hukou system, Chinese urban migrants rarely build their own houses, either living in employer-provided accommodation or renting rooms from established residents. The 1997 Beijing survey reports that almost 50\% of migrants stayed in workrelated housing and another 25\% in rented dwellings. In the same year in Shanghai, about one-third of migrants labeled "temporary" lived in dormitories and another third in rentals (Wu, 2002). As a result, it should be clear that the hukou system is quite inefficient since it makes rural migrants (i.e. non-hukou holders) separated in the social, physical, and labor market spaces. In 2005, 74 million people with rural hukou lived in cities (Henderson, 2009). Furthermore, migrants tend to leave the countryside at age 1617 and rarely return. As a result, rural-urban migration tends to be permanent and the big issue is the distinction between formal and informal sector markets. The latter (i.e. informality) is not that good because basically rural migrants do not learn much by migrating to cities since, as Solinger (1999) put it, they "take up most of the 3-D (Dirty, Dangerous and Demanding) jobs shunned by urban workers." In particular, they do not 
interact with urban residents, who are usually more educated, and thus don't benefit from local externalities.

In this context, social housing for rural (illegal) migrants could be efficient since it would make the informal sector formal and would allow rural migrants to live in decent housing. By social housing, we mean (directly or indirectly) subsidizing housing for the poor by either targeting places or people (see our answer to question (1) above).

Indeed, after 2002, rural-urban hukou conversions were decentralized to provinces and there has been an upsurge in hukou conversions. According to Henderson (2009), an estimate of 90 million of such conversions has occurred between 2000 and 2007. These 90 million represent permanent migration. This is coupled with a farm labor force still in excess of 300 million, perhaps 200 million of which are truly excess labor. As a result, there is a clear tendency for making rural migration permanent. So social housing would certainly improve the living conditions of rural (permanent) migrants by providing them with decent housing.

One worry with giving subsidized housing to migrants is that it encourages more migration into cities like Beijing where such encouragement is problematic. There is therefore a trade off between equity (migrants versus non-migrants for housing) and efficiency (subsidizing in-migration effectively). Indeed, on the one hand, giving subsidies to migrants will encourage more migration. On the other hand, you want them to live in decent housing condition. In Song and Zenou (2010), we show for the city of Shenzhen that the price of land of non urban-village residents is negatively affected by nearby urban villages. In other words, the closer one resides from an urban village, the higher are the negative externalities this person gets (especially in terms of the value of his/her house). So even if the local government totally ignores illegal migrants and urban villages, it cannot ignore the fact that it affects urban hukou holders who live nearby these urban villages.

Finally, if the Chinese government continues to ease the hukou rules, then there will be important effects on both the demand and the supply sides. On the demand side, the easing of hukou rules will stimulate demand for low income housing outside the urban villages in cities. This will encourage the filtering of existing housing to serve these households. But these are very poor households, so we should be wary of rules and standards imposed outside of the urban villages that do not allow low quality housing to be supplied to the poor. Public health and safety are crucial concerns of government, but rules on crowding, privacy, and shared facilities, may quickly become excessive. On the supply side, we should not encourage substantial upgrading of housing in the urban villages beyond the capacity of the poor to pay. We'd prefer a glut of slum housing to its elimination -- driving down the cost of accommodation. We should encourage the integration of land use planning in cities to include the urban villages, but we should be careful not to let this reduce the supply of low income housing. Ideally, subsidy programs for renters should be demand-oriented (vouchers and the like, i.e. person-targeted policy). But since so many of the urban poor and emancipated rural migrants work in the informal sector, it would be hard to identify eligibles and to manage such a program. As a result, a place-targeted policy could be more efficient. 


\section{(3) Should we encourage or suppress urban villages in China?}

Rural migrants are constrained in several aspects. Most of rural migrant laborers are taking low-income jobs in cities, which limits their capacity to consume urban housing units in the commercial housing market. Albeit working longer hours, rural migrants earn less income (for example, 18\% lower in 1999) than urban residents (Liu, et al., 2003). They are thus constrained by their financial capabilities. In addition, migrants are excluded from the urban housing market because of institutional restrictions associated with the urban hukou system. As such, programs aiming at eliminating urban villages and improving physical environment in urban villages would likely be largely ineffectual and harmful to China's economy. As stated above, without complementary consideration of re-housing current rural migrants, the renewal of villages within cities is obviously a planning action at the expense of rural migrants.

To be more precise, I believe that urban villages play an important role in accommodating rural migrants. This is a realistic solution, however, only in the short run. But, as stated above, these villages are totally separated from other areas in the city, which means that there are no interactions between urban residents and illegal migrants living in urban villages. As a result, in the long run, the government should officially recognize these urban villages and provide the rural migrants with decent social housing. Unless the Chinese government wants these villages to become favelas (as in Brazil), it should bring them under urban governance and planning, and provide them with local public services. This may be delicate act (respecting the property rights of the original villages), while moving them under urban rather than collective governance.

\section{(4) Should China create jobs in rural areas?}

This could be done following the example of the Entreprise Zone (EZ) or empowerment zone programs implemented both in the US and in Europe. For China, it would be interesting to have enterprise zone programs in rural areas to attract firms establishing there. This would be a complementary policy to those advocated in urban areas (see our answer to question (1)). All firms that become established in these areas would be exempted from tax (pay-rolls taxes) during a certain period (typically five years). The idea of this policy is to decrease the "distance" between local rural workers and firms and help these workers stay in rural areas. In return, each firm must hire 20-30 percent of their employees from the local rural population. As stated above, this is a place-oriented policy and it should be implemented together with a people-oriented policy such as the MTO programs.

\section{(5) Can microfinance work in China?}

An alternative policy (implemented in Africa and India) to public housing that can help improve access to affordable housing and reduce the spread of slums is microfinance.

Chapters 6 and 7 of United Nations Habitat (2005) provide a well-informed discussion of recent developments. The chapters contrast four forms of loans, mortgage finance by banks, microenterprise finance, shelter microfinance, and community funds. Microenterprise finance is targeted to small entrepreneurs, shelter microfinance to 
households with land who wish to improve their structures, and community funds to those without secure tenure for the construction of basic housing and infrastructure. A dominant theme is that shelter microfinance agencies and community organizations need links to the state to provide funding on the required scale but that establishing these links carries with it the dangers of bureaucratization.

Let us explain in more detail how microfinance works and how it can be applied to China. ${ }^{31}$ Microfinance has established itself as an integral part of financial sector policies of developing countries in the past decade. The practice started in the 1970s as a pilot project in Bangladesh and has rapidly spread around the globe. Currently around 70 million low-income individuals are served by microfinance institutions (Daley-Harris, 2003). The essence of microfinance is to draw ideas from existing "informal sector" credit mechanisms - like intra-family loans, Rotating Savings and Credit Associations (ROSCAs), and local moneylenders - while creating a viable conduit for capital infusions from formal sector banks, donors, and governments. Because of the lack of formal financial institutions in urban villages for rural migrants in China, subsidies to entrepreneurs can be channeled through state-run banks, as for example the famous Grameen Bank in India, which lend money to the poor at reasonable interest rates and without requiring collateral. It works as follows. The Grameen Bank holds a meeting in a village and announces that it will soon introduce a new kind of banking operation. Individuals interested in borrowing will get loans for their own, independent projects, but they must approach the bank with four others who similarly seek loans. These five-person groups meet with a loan officer from the bank once each week, at which time loans are disbursed and payments are made. The loan contract has a twist, which is that should a borrower be unable to repay his/her loan, he/she will have to quit his/her membership of the bank - as will his/her four fellow group members. While the others are not forced explicitly to repay for the potential defaulter, they have clear incentives to do so if they wish to continue obtaining future loans. The key is that Grameen Bank loans (like loans from other microlenders) are more attractive than loans from other sources like moneylenders. While moneylenders may charge interest rates over 100 per cent per year, the Grameen Bank keeps its official rates at 20 per cent (and even with extra fees, effective rates are below 30 per cent per year).

Allowing borrowers to voluntarily form their own groups helps microlenders overcome an "adverse selection" problem (Ghatak, 2000; Armendáriz de Aghion and Gollier, 2000). The problem is that a traditional bank has a difficult time distinguishing between inherently "risky" and "safe" borrowers in its pool of loan applicants; if it could, the bank would charge a high interest rate to the risky borrower and a lower one to the safe borrower. But without precise information, the bank must charge the same (high) rates to all potential borrowers, and this can trigger the exit of safe borrowers from the credit market (this is referred to as the "lemon" problem; see Akerlof, 1970). The outcome is inefficient since, in an ideal world, projects undertaken by both risky and safe borrowers should be financed. One advantage of the group lending methodology (at least in principle) is that it can put local information to work for the outside lender. Adverse selection is mitigated under the group lending methodology.

31 For an overview, see, in particular, Armendariz de Aghion and Morduch (2005) and Yunus (2008). 
There is no reason why this should not work in China. Microfinance could be an alternative (or a complement) to creating jobs and increasing the education level in rural areas. Indeed, we should give migrants the opportunity to create jobs or start their own projects, either at home (in the rural area) or in the city. Migrants in China are generally very entrepreneurial (see e.g. Ma, 2002) with many "self-employed" -- the question is how they finance their projects. Microfinance could be a good way to achieve this goal. As in India (Merill, 2009), microfinance could also help provide adequate shelter and sanitation for the very poor, especially in rural areas.

\section{References}

Akerlof, G.A. (1970), “The market for 'lemons': Quality uncertainty and the market mechanism," Quarterly Journal of Economics 84, 488-500.

Arnott, R. (1987), "Economic theory and housing," In: E.S. Mills (Ed.), Handbook of Regional and Urban Economics, pp. 927-956.

Arnott, R. (1989), "Housing vacancies, thin markets, and idiosyncratic tastes," Journal of Real Estate Finance and Economics 2, 5-30.

Arnott, R. (2009), "Housing policy in developing countries: The importance of the informal economy,” In: M. Spence, P. Clarke Annez, and R.M. Buckley (Eds.), Urbanization and Growth, Washington, DC: The World Bank, pp 167-196.

Armendáriz de Aghion, B. and C. Gollier (2000), "Peer group formation in an adverse selection model,” Economic Journal 110, 632-643.

Armendariz de Aghion, B. and J. Morduch (2005), The Economics of Microfinance, Cambridge, MA: MIT Press.

$\mathrm{Au}$, C.C. and J.V. Henderson (2006a), "How migration restrictions limit agglomeration and productivity in China," Journal of Development Economics 80, 350-388.

$\mathrm{Au}$, C.C. and J.V. Henderson (2006b), "Are Chinese cities too small," Review of Economic Studies 73, 549-576.

Bachin, P. (1996), Housing Policy in Europe, London: Routledge.

Bisin, A., E. Patacchini, T. Verdier, and Y. Zenou (2009), "Ethnic identity, residential segregation, and labor-market outcomes of immigrants in Europe,” Unpublished manuscript, Stockholm University.

Boarnet, M.G. and W.T. Bogart (1996), "Enterprise zones and employment: Evidence from New Jersey,” Journal of Urban Economics 40, 198-215.

Bondonio, D. and J. Engberg (2000), "Enterprise zones and local employment: Evidence from the states’ program," Regional Science and Urban Economics 30, 519-549.

Bondonio, D. and R.T. Greenbaum (2007), "Do local tax incentives affect economic growth? What mean impact miss in the analysis of enterprise zone policies,” Regional Science and Urban Economics 37, 121-136.

Bover, O., J. Muellbauer, and A. Murphy (1989), "Housing, wages and UK labour markets," Oxford Bulletin of Economics and Statistics 51, 97-136.

Brueckner, J.K. (1986), "The downpayment constraint and housing tenure choice: A simplified exposition,” Regional Science and Urban Economics 16, 519-525.

Brueckner, J.K. (2000), “Urban sprawl: Diagnosis and remedies,” International Regional Science Review 23, 160-71. 
Busso, M. and P. Kline (2009), "Do local economic development programs work? Evidence from the federal empowerment zone program," Unpublished manuscript, University of California, Berkeley.

Chan, K.W., Liu, T., and Y. Yang (1999), "Hukou and non-hukou migrations in China: Comparisons and contrasts," International Journal of Population Geography 5, 425-448.

Chan K.W. and L. Zhang (1999), "The hukou system and rural-urban migration in China: Processes and changes," China Quarterly 160, 818-855.

Charles, K.K. and E. Hurst (2002), "The transition to home ownership and the blackwhite wealth gap," Review of Economics and Statistics 84, 281-297.

Coogan, M. (1998), "Recent developments in the UK housing and mortgage markets," Housing Finance International, 12, 3-9.

Daley-Harris, S. (2003), The State of the Microcredit Summit Campaign 2003. Washington, DC: Microcredit Summit.

Dietz, R.D. and D.R. Haurin (2003), "The social and private micro-level consequences of homeownership,” Journal of Urban Economics 54, 401-450.

Doling, J. (2006), “A European housing policy?” European Journal of Housing Policy 6, 335-349.

Eastaway, M.P. and I.S.M. Varo (2002), "The tenure imbalance in Spain: The need for social housing policy,” Urban Studies 39, 283-295.

Engelhardt, G.V. (1994), "House prices and the decision to save for down payments," Journal of Urban Economics 36, 209-237.

European Commission (1998), Housing Statistics in the European Community 1998, Brussels: European Commission DG V.

Englund, P. (2003), “Taxing residential housing capital," Urban Studies, 40, 937-952.

Ghatak, M. (2000), "Joint liability credit contracts and the peer selection effect," Economic Journal 110, 601-631.

Gibb, K. and C. Whitehead (2007), "Towards the more effective use of housing finance and subsidy,” Housing Studies 22, 183-200.

Government of India (1997), Ministry of Urban Affairs \& Employment: Prominent Facts on Housing.

Green, R. and P.H. Hendershott (2001), "Home-ownership and unemployment in the US,” Urban Studies 38, 1509-1520.

Green, R. and S. Malpezzi (2003), A Primer on U.S. Housing Markets and Housing Policy, Washington, DC: Urban Institute Press.

Groves, R., A. Murie and C. Watson (2007), Housing and the New Welfare State. Perspectives from East Asia and Europe, Burlington, VT: Ashgate.

Ha, S-K. (2007), "Housing regeneration and building sustainable low-income communities in Korea," Habitat International 31, 116-129.

Haurin, D.R., P.H. Hendershott, and S.M. Wachter (1996), "Wealth accumulation and housing choices of young households: An exploratory investigation," Journal of Housing Research 7, 33-57.

Henderson, J.V. (2009), “Urbanization in China: Policy issues and options,” Unpublished manuscript, Brown University.

Hills, J. (2007), "Ends and means: The future roles of social housing in England,” LSE, CASE Report 34. 
Hirayama, Y. (2007), "Housing and state strategy in post-war Japan,” In: R. Groves, A. Murie and C. Watson (Eds.), Housing and the New Welfare State. Perspectives from East Asia and Europe, Burlington, VT: Ashgate, pp. 101-126.

Hubert, F. (2006), “The economic theory of housing tenure choice” In: R. Arnott and D. McMillen (Eds.), A Companion to Urban Economics, Boston: Blackwell Publishing, pp. 145-158.

Hughes, G. and B. McCormick (1987), "Labour market inflexibility, housing policy, and unemployment,” European Economic Review 31, 615-641.

Hughes, G. and B. McCormick (1990), "Measuring unemployment and cyclical participation in the British labour market," Scandinavian Journal of Economics 92, 247-269.

Hoogstra, G.J., J. van Dijk and R. Florax (2010), "Determinants of variation in population-employment interaction findings: A quasi-experimental metaanalysis,” Geographical Analysis, forthcoming.

Ihlanfeldt, K.R. (2006), “A primer on spatial mismatch within urban labor markets,” In: R. Arnott and D. McMillen (Eds.), A Companion to Urban Economics, Boston: Blackwell Publishing, pp. 404-417.

Ihlanfeldt, K. R. and D. Sjoquist (1998), "The spatial mismatch hypothesis: A review of recent studies and their implications for welfare reform," Housing Policy Debate 9, 849-892.

Jaffee, D.M. and J.M. Quigley (2007), "Housing subsidies and homeowners: What role for government-sponsored enterprises? Brookings-Wharton Papers on Urban Affairs 103-149.

Jones, L.D. (1995), “Testing the central prediction of housing tenure transition models," Journal of Urban Economics 38, 50-73.

Kain, J.F. (1968), "Housing segregation, negro employment, and Metropolitan decentralization," Quarterly Journal of Economics 82, 175-197.

Kanemoto, Y. (1997), “The housing question in Japan,” Regional Science and Urban Economics 27, 613-641.

Katz, L.F., Kling, J.R. and J.B. Liebman (2001), "Moving to opportunity in Boston: Early results of a randomized mobility experiment," Quarterly Journal of Economics 116, 607-654.

Katz, B. and M.A. Turner (2008), "Rethinking U.S. rental housing policy: A new blueprint for federal, state, and local action,” In: N.P. Retsinas and E.S. Belsky (Eds.), Revisiting Rental Housing. Policies, Programs, and Priorities, Washington, DC: Brookings Institution Press, pp. 319-358.

Kling, J.R., Ludwig, J., and L.F. Katz (2005), "Neighborhood effects on crime for female and male youth: Evidence from a randomized housing Voucher experiment," Quarterly Journal of Economics 120, 87-130.

Ladd, H.F. and J. Ludwig (1997), "Federal housing assistance, residential relocation, and educational opportunities: Evidence from Baltimore," American Economic Review 87, 272-277.

Laferrère, A. and D. Le Blanc (2004), "How do housing allowances affect rents? An empirical analysis of the French case,” Journal of Housing Economics 13, 36-67. 
Laferrère, A. and D. Le Blanc (2006), "Housing policy: Low-income households in France," In: R. Arnott and D. McMillen (eds.), A Companion to Urban Economics, Boston: Blackwell Publishing, pp. 159-178.

Lee, J. (2000), "From welfare housing to home-ownership: The dilemma of China's housing reform," Housing Studies 15, 61-67.

Liu, S., Li, X. and M. Zhang (2003), "Scenario analysis on urbanization and rural-urban migration in China,” Interim report submitted to International Institute for Applied Systems Analysis, http://www.iiasa.ac.at/Publications/Documents/IR-03036.pdf.

Ludwig, J., Duncan, G.J. and P. Hirschfield (2001), "Urban poverty and juvenile crime: Evidence from a randomized housing-mobility experiment,” Quarterly Journal of Economics 116, 655-679.

Ma, Z. (2002), "Social-capital mobilization and income returns to entrepreneurship: the case of return migration in rural China," Environment and Planning A 34, 17631784.

Mahadeva, M. (2006), "Reforms in housing sector in India: impact on housing development and housing amenities," Habitat International 30, 412-433.

Merill, S.R. (2009), "Microfinance for housing: Assisting the "bottom billion" and the “missing middle”," Working Paper No. 2009-05, Urban Institute Center on International Development and Governance.

Minford, P., Peel, M. and P. Ashford (1987), The Housing Morass, London: Institute of Economic Affairs.

Mobrand, E. (2006), "Politics of city ward migration: An overview of China in comparative perspective,” Habitat International 30, 261-274.

National Buildings Organisation (2003), Handbook of Housing Statistics, http://nbo.nic.in/Webforms/publications.html.

National Low Income Housing Coalition (2005), "An initial estimate of the number of people with housing problems from the 2003 American Housing Survey," Research Note No. 05-01, http://www.nlihc.org/research/05-01.pdf.

Olsen, E.O. (2003), "Housing programs for low-income households," In: R. Moffitt (Ed.), Means-Tested Transfer Programs in the United States, Chicago: Chicago University Press, pp. 365-442.

Oswald, A. (1999a), “The housing market and Europe’s unemployment: A non-technical paper," Available at: http://www.warwick.ac.uk/.

Oswald, A. (1999b), “Buy your home and kill a job,” New Statesman, 28 June, 10-11.

Papke, L. (1994), "Tax policy and urban development: Evidence from the Indiana enterprise zone program," Journal of Public Economics 54, 37-49.

Park, S-Y. (2007), “The state and housing policy in Korea,” In: R. Groves, A. Murie and C. Watson (Eds.), Housing and the New Welfare State. Perspectives from East Asia and Europe, Burlington, VT: Ashgate, pp. 75-100.

Peters, A.H. and P.S. Fisher (2002), State Enterprise Zone Programs: Have They Worked? Kalamazoo, MI: W.E. Upjohn Institute for Employment Research.

Phang, S-Y. (2007), "The Singapore model of housing and the welfare state," In: R. Groves, A. Murie and C. Watson (Eds.), Housing and the New Welfare State. Perspectives from East Asia and Europe, Burlington, VT: Ashgate, pp. 15-44. 
Quigley, J.M. (1997), The Economics of Housing and Housing Markets, London: Edward Elgar.

Quigley, J.M. (2008), “Just suppose: Housing subsidies for low-income renters,” In: N.P. Retsinas and E.S. Belsky (Eds.), Revisiting Rental Housing. Policies, Programs, and Priorities, Washington, DC: Brookings Institution Press, pp. 300-318.

Quigley, J.M. and S. Raphael (2008), "Neighborhoods, economic self-sufficiency, and the MTO,” Brookings-Wharton Papers on Urban Affairs 8, 1-46.

Ramesh, M. (2004), "One-and-a-half cheers for provident funds in Malaysia and Singapore," paper prepared for the UNRISD project on Social Policy in a Development Context.

Read, C. (1997), "Vacancies and rent dispersion in a stochastic search model with generalized tenant demand," Journal of Real Estate Finance and Economics 15, 223-237.

Retsinas, N.P. and E.S. Belsky (2008), Revisiting Rental Housing. Policies, Programs, and Priorities, Washington, DC: Brookings Institution Press.

Rosenbaum, E. and L.E. Harris (2001), "Residential mobility and opportunities: Early impacts of the Moving to Opportunity demonstration program in Chicago," Housing Policy Debate 12, 321-346.

Rosenthal, S.S. (2008), "Where poor renters live in our cities: Dynamics and determinants,” In: N.P. Retsinas and E.S. Belsky (Eds.), Revisiting Rental Housing. Policies, Programs, and Priorities, Washington, DC: Brookings Institution Press, pp. 59-92.

Scanlon, H. and C. Whitehead (2004), "Housing tenure and mortgage systems: A survey of nineteen countries,” Paper presented at the ENHR Conference, Cambridge.

Schwartz, A.F. (2006), Housing Policy in the United States. An Introduction, New York: Routledge.

Seko, M. (1994), "Housing finance in Japan,” In: Y. Noguchi and J. Poterba, (Eds.), Housing Markets in the United States and Japan, Chicago: University of Chicago Press, pp. 49-64.

Solinger, D.J. (1999), Contesting Citizenship in Urban China: Peasant Migrants, the State, and the Logic of the Market, Berkeley: University of California Press.

Song, Y., G. Knaap, and C. Ding (2005), "Housing policy in the People's Republic of China: An historical review,” In: C. Ding and Y. Song (Eds.), Emerging Land and Housing Markets in China, Cambridge, MA: Lincoln Institute of Land Policy.

Song, Y., Y. Zenou, and C. Ding (2008), "Let's not throw the baby out with the bath water: The role of urban villages in housing rural migrants in China," Urban Studies 45, 313-330.

Song, Y. and Y. Zenou (2010), "Urban villages and housing values in China," Unpublished manuscript, Stockholm University.

South, S.J. and K.D. Crowder (1997), "Escaping distressed neighborhoods: Individual, community, and metropolitan influences,” American Journal of Sociology 102, 1040-1084.

United Nations Habitat (2005), Financing Urban Shelter: Global Report on Human Settlement 2005, London: Earthscan and UN Habitat.

Wang, F. and X. Zuo (1999), “Inside China's cities: Institutional barriers and opportunities for urban migrants,” American Economic Review 89, 276-280. 
Wheaton, W.C. (1990), "Vacancy, search, and prices in a housing market matching model,” Journal of Political Economy 98, 1270-1292.

Whitehead, C. (1999), "Urban housing markets: Theory and policy," In: P.C. Cheshire and E.S. Mills (Eds.), Handbook of Regional and Urban Economics, Vol. 3, Amsterdam: North Holland, pp. 1559-1594.

Wu, W. (2002), “Temporary migrants in Shanghai: Housing and settlement patterns,” In: J. R. Logan (Ed.), The New Chinese City: Globalization and Market Reform, Malden: Blackwell Publishers, pp. 212-226.

Wu, W. (2004), “Sources of migrant housing disadvantage in urban China," Environment and Planning A 26, 1285-1304.

Yunus, M. (2008), Creating a World Without Poverty: Social Business and the Future of Capitalism, New York: Public Affairs.

Zenou, Y. (2009a), “How common is integration policy in Europe?” In: S. Gustavsson, L. Oxelheim, and Lars Pehrson (Eds.), How Unified in the European Union, Berlin: Springer Verlag, pp. 139-155.

Zenou, Y. (2009b), Urban Labor Economics, Cambridge: Cambridge University Press.

Zhang, L., Zhao, S.X.B. and J.P. Tian (2003), "Self-help in housing and Chengzhongcun in China's urbanization,” International Journal of Urban and Regional Research 27, 912-937. 